Vol. 8 (1999): 393-410.

\title{
The total material requirement -concept applied to agriculture: a case study from Finland
}

\author{
Helmi Risku-Norja \\ Agricultural Research Centre of Finland, Resources Management Research, FIN-31600 Jokioinen, Finland, \\ e-mail: helmi.risku-norja@mtt.fi
}

In connection with the concept of sustainability emphasising the interaction of the economy and nature the material flow accounting (MFA) approach has in recent years obtained new relevance and is presently under vivid development. In this study, the concept of the total material requirement (TMR) of the MFA methodology has been applied to agriculture in Finland. The present level and development trends in use of natural resources since the beginning of the 1970's are described. The objective is to show the feasibility of the approach, to point out the reduction possibilities within the agriculture and to provide tools to set clear quantitative goals for reduction. There appears to be an urgent need to develope new methods, because several of the TMR-based indexes cannot be applied within the agricultural sector as such. Three indexes - $\sum$ direct material input (DMI)/energy consumption, $\Sigma D M I /$ use of commercial fertilisers, $\Sigma D M I /$ use of biocides - are suggested to measure the resource efficiency and the tempo of change towards sustainability. Some of the problems are directly related to the lack of adequate and internationally comparable data. The study is part of the national ecoefficiency-project with the overall aim to analyse the dependence of the natural resource use from the structure and growth of the economy, to localise the strategic targets of dematerialisation of the economy and to create a coherent and internationally comparable database to be used in developing environmental indicators.

Key words: agriculture, crop production, direct material input (DMI), eco-efficiency, environmental indicator, hidden flows, material flow accountig (MFA), sustainability, time series, total material requirement (TMR)

\section{Introduction}

The world-wide continuous growth of the production and consumption is based on the energy and raw materials obtained ultimately from nature. For human beings, nature is the source of raw materials and, at the same time, the waste sink; all materials we use are derived from nature and there they are at the end returned, often from nature's point of view in an altered form and in wrong places. As the consequence of the economic activities a continuos throughput of various materials is created from nature into the

\section{(C) Agricultural and Food Science in Finland}

Manuscript received June 1999 


\section{AGRICULTURAL AND FOOD SCIENCE IN FINLAND}

\section{Risku-Norja, H. The total material requirement -concept applied to agriculture}

antroposphere and back to nature. The current production patterns have rapidly proved to be increasingly unsustainable because, in connection of the extraction of natural resources, huge masses of materials are translocated, transformed, used and finally returned back to the nature as wastes and emissions. At the same time, the environment is being severely altered in vast areas. Beside the exhaustive use of natural resources, the damage caused by the current material throughput of economic activities to the natural ecosystems has been realised as one of the key factors threatening the sustainable development.

The impact of human economy on the ecosystems must be radically cut down. This requires that the environmental impact can be quantified with internationally uniform methods. The Wuppertal Institute of Climate and Environment in Germany and the European ConAccount - the concerted action "Coordination of Regional and National Material Flow Accounting for Environmental Sustainability" have during the 1990's actively developed material flow accounting (MFA) as such a tool (ConAccount 1998). In recent years MFA methods have obtained increasing relevance as means to assess the extent of exploitation of natural resources and MFA is being developed to an additional indicator for sustainability. Within the 4th framework programme of EC the MAcTEmPo -project (Materials Accounting as a Tool for Decision Making in Environmental Policy) has supplied tools based on materials accounting for decision makers in environmental protection and resource conservation (MAcTEmPo 1997). In the European Environment Agency the MFA-methodology has been accepted and its role within the European Environmental Information System is becoming increasingly important (Beltrán 1997). In Finland, the material flow accounting is being developed in co-operation with Eurostat as a part of NAMEA, the national green account for a tool to follow up the use of natural resources (Hoffrén 1998).

Material flow approach traces back to the late 1960's, when the main concern was the threat of exhaustion of natural resources (Boulding 1966, Daly 1968, Ayers and Kneese 1969, Meadows et al. 1971). With discovery of new reserves, technological development and substitution of materials the threat proved to be premature and consequently, the interest shifted to the end-ofpipe thinking. The interaction of the economy and nature was brought again into focus in a profound and comprehensive way with the introduction of the concepts sustainable development and industrial metabolism in the late 1980's (e.g. WCED 1987, Ayers 1989a, b, Erkman 1997). In addition to the traditional end of pipe- thinking, the significance of the input side of the economy has now been realised. Exploitation of natural resources destroys nature and interferes with its functioning. The quantity and quality of the various material flows determine the impact of economic activity on the ecosystems. Because of the law of material indestructibility the consequences depend on the total material throughput. By reducing the volume of the extracted natural resources the undesirable effects on environment at the front end of the nature-antroposphere interface can be diminished. At the same time, the environmental burden is prevented in advance, because the reduction of the material flows inevitably results in reduced amounts of wastes and emissions thus diminishing environmental burden also at the end of the material flow (Hinterberger et al. 1997). Increasing resource productivity is also economically profitable, because savings are gained in lowered material and transport costs and in costs of pollution control (Repetto et al. 1996, Ayers 1997).

\section{Ecoefficiency}

Reducing the material flows is closely connected to the ecoefficiency concept. Ecoefficiency is a diffuse term lacking exact meaning. Broadly speaking, it is used to describe generally the social strategies aiming at lowering the environmental burden without decreasing human welfare or the total profitability of production. In practice, this means dematerialization of the 
Vol. 8 (1999): 393-410.

economy by producing more out of less (Spangenberg 1995). This can be accomplished by introducing holistic strategies for planning environmentaly sounder production.

Ecoefficiency is also used with a more precise meaning as an index to measure the effects of production on environment and economy. In that case, ecoefficiency is defined as the natural resource use per unit gross national product. The ultimate aim of ecoefficiency is to increase resource efficiency by reducing the use of energy and materials per production unit and, at the same time, to create cost savings and competitive advantage (OECD 1997, KTM 1998, Hoffrén 1999).

Improving labour productivity by intensifying the use of energy and materials has been the basic concept in all economic activities already before awakening of the environmental awareness. The essence of the ecoefficiency is to shift the focus from labour productivity to resource productivity, which is the precondition for sustainable production and economy (Höhn 1997). Increasing ecoefficiency provides new possibilities for integrated environmental protection, and it is, therefore, one of the central topics within the commission for sustainable development of the United Nation (UN 1995). This goal is also clearly stated in the Council of State decisionin-principle on the promotion of ecological sustainability (Ympäristöministeriö 1998).

\section{The factors and measuring the ecoefficiency}

The aims of increasing ecoefficiency are concretised with the Factor-goals, which have been defined to guide the change in the production and consumption patterns. The medium-term objective by the year 2030 is to cut down the use of natural resources to one fourth, and and within the longer term by the year 2050 , to one tenth part compared to the present level of consumption. This does not necessarily lead to a contradiction with the goals of growing econo- my and welfare. The same goal can be reached by decreasing the raw materials and energy input of production, increasing the production per unit input or by carrying out both measures simultaneously (Factor 10 Club 1997, Lovins et al. 1997, Weizsäcker et al. 1997).

In order to clearly quantify the aims, the present level and the development trends of the consumption must be known. Only then it is possible to localise the targets, where the use of natural resources can be radically reduced. The follow-up of the realisation of the aims requires objective measuring instruments. The total material requirement (TMR) comprises all material flows induced by the production. TMR/GNP is one of the indexes based on the total consumption of natural resources developed at the Wuppertal Institute. Others are ecological rucksacks, which can be expressed as the hidden material flows per capita or the hidden material flows per product, the share of the hidden flows or the share of the import from the TMR and the material intensity per unit service (MIPS) (SchmidtBleek 1993, Lettenmeier 1998, Schmidt-Bleek 1998, Schmidt-Bleek et al. 1998). Another approach is the ecological footprint -concept, with which is meant the area of biologically productive land needed to maintain the prevailing consumption patterns at national, regional, local or personal level (Wackernagel and Rees 1996). Environmental space, on the other hand, refers to the amount of natural resources each human being is yearly entitled to without the carrying capacity of the nature being exceeded (Carley and Spapens 1998, Spapens 1998).

\section{Material flows and the goals of the study}

Analysing material flows is an additional approach to assess the realisation of sustainable development. The acronym MFA stands both for material flow accounting and material flow analysis. The MFA research is concerned in developing methods to measure the use of natural resources and to allocate the material flows within the various sectors of the economy. In this 


\section{AGRICULTURAL AND FOOD SCIENCE IN FINLAND}

\section{Risku-Norja, H. The total material requirement -concept applied to agriculture}

context the term "material" is used as the synonym of natural resources. The term "natural resources" is not restricted to economically exploitable resources, but is understood in a broad meaning comprising the ecosystems as the source of materials and as the target of human measures. The method developed at the Wuppertal Institute is based on this concept (Bringezu 1997). The "materials" of MFA have been defined also in a more rigorous way comprising single elements or pure chemical compounds, of which the various products are made. This school of research - the substance flow analysis - is concerned in defining and balancing substance flow systems, and MFA has been developed as a tool for analysing regional metabolism on the substance level (Baccini and Brunner 1991, Burström 1998, Burström et al. 1997, Burström et al. 1998, Frostell et al. 1998, Lindqvist and Eklund 1999, Sörme 1999, Voet et al. 1995, 1996, 1997). The broad umbrella MFA houses both approaches (Bringezu and Moll 1998).

In this study the Wuppertal approach has been adapted. The approach is based on the total material requirement including the direct material inputs and the so-called hidden flows. The direct material inputs comprise those materials the various products are made of. The flow of materials through the economy consists also of the hidden flows. The hidden flows are those natural resources, which are handled during the production of the commodities, but which are not included within the final product. TMR can, thus, be considered as the basic factor in causing environmental burden. When assessing the volumes of material flows, the use of natural resources caused by the domestic consumption abroad must also be accounted for. This is because with globalisation of the world trade, the raw materials of the products often originate and they are refined elsewhere than the final products are consumed. Considering only the domestic production would lower the national TMR, since the hidden flows associated with the imported goods, including those of transportation, would be ignored (Adriaanse et al. 1997, Schütz and Bringezu 1998). The use of materials can be made more efficient by recycling. There is a limit for that, too: when the energy that is required for recycling exceeds the energy obtained from it, recycling is not reasonable anymore (Hinterberger 1994).

The first international application of the method was the joint study, in which the time series of the development on the TMR during 1970-1994 in four countries - Germany, Japan, the Netherlands and the USA - were formed (Adriaanse et al. 1997). Data produced by the same method and same calculation principles are now available also from Austria (Hüttler et al. 1999), Italy (deMarco et al. 1999) as well as from Australia and Poland and will be soon available from Sweden, (ref. Juutinen and Mäenpää 1999). In Finland, the method has been used in a national ecoefficiency project, in which the TMR and its reduction possibilities in agriculture, forestry and mining sectors are clarified. The considered time period from 1970 to 1997 is long enough to reveal the overall trend of and the changes in the material intensity of the various sectors. The ultimate aim is to analyse the dependence of the natural resource use from the structure and growth of the economy, to localise the strategic targets of dematerialisation of the economy and to create a coherent and internationally comparable database to be used in developing environmental indicators. Preliminary results show that the yearly TMR in Finland is of the same order of magnitude as in other industrialised countries, about 90 tons per capita. In Finland the TMR per capita and per gross national product have increased up to the beginning of the 1990's, but have levelled out since then (Adriaanse et al. 1997, ECOEFF 1999).

This study is part of the national project, and provides the data for agriculture. To assure international comparability the data have been gathered and treated in accordance with the guidelines defined by Adriaanse et al. (1997) and by Juutinen and Mäenpää (1999). The objective is to describe the present level and development trends in use of natural resources, to discuss the applicability of the approach to agriculture, to point out the reduction possibilities and to de- 
Vol. 8 (1999): 393-410.

velope tools to define clear quantitative goals for reduction.

\section{The material flows in agriculture}

Considering the material flows caused by agriculture, the materials can - modifying the grouping of Eurostat - be roughly classified into three different groups. The various biocides represent flows, which even in very small quantities are very hazardous to the environment. The use of these substances is under strict control and the injurious effects are attempted to be minimised by the chemical laws and regulations. 2 . The soil fertilisers and fossil energy are non-renewable natural resources used in agriculture. The aim is to reduce their use by increasing the resource efficiency, promoting the nutrient recycling and by finding substituting renewable raw materials. The plant production represents renewable raw materials. Its share from the TMR can be increased by improving ecoefficiency, i. e. by producing more with lesser inputs. 3 . The cultivated land area, the soil eroded from the fields and the irrigation water are as such non-poisonous materials. However, when extracting natural resources these substances create yearly very large material flows, which alter natural ecosystems thoroughly, continuously and world-wide. Except for few individual cases, the consequences of these material flows have been so far largely ignored. Environmental discussion has traditionally concentrated in pollutants, in repairing damages afterwards and in controlling symptoms. Concerning the supply of the raw materials, the discussion is focused on the second group of materials. Lately also the flows formed from the third group of materials have been gradually realised as a serious threat to biodiversity and sustainable development.

In agriculture, the direct material inputs are represented by the plant production. When the material flows are considered at the national level, the hidden flows of agriculture comprise the cultivated soil, the raged land areas, when the

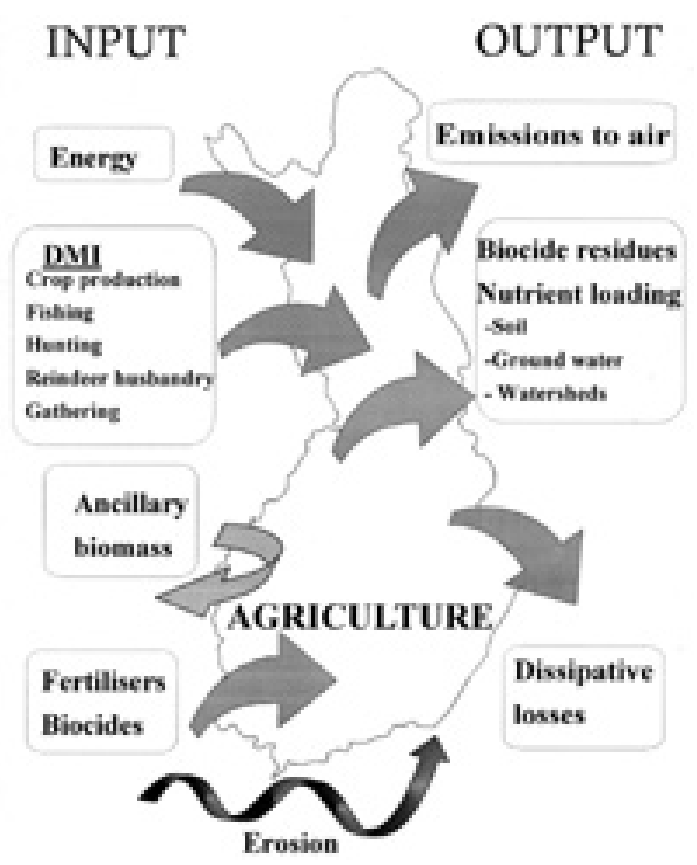

Fig. 1. The material throughput of the agriculture and related production sectors.

land is taken for cultivation, and the ancillary biomass of the plant production. At the sector level, the hidden flows include also the various soil fertilisers, biocides and growth regulators as well as the energy consumption. International comparability requires that water and air are not accounted for (Adriaanse et al. 1997). Recycling in agriculture is realised already quite effectively, because the ancillary biomass is tilled back into the field already during the harvesting phase. In doing this a significant part of the nutrients are returned back into the field. In addition, the organic material improves the quality of the soil by making it more porous and by binding the particles together decreasing thus its erodibility (Imeson and Kwaad 1990, Evans 1995). The problem is the dissipative losses returned back to the nature as the consequence of gradual degradation or of losses from the production. This is seen as erosion, nutrient loading in the watersheds and as biocide residues in the soil, watersheds and groundwater (Fig. 1). 


\section{AGRICULTURAL AND FOOD SCIENCE IN FINLAND}

\section{Risku-Norja, H. The total material requirement -concept applied to agriculture}

The commonly used TMR-based indexes cannot be applied to agriculture as such, because the production depends on the area of cultivated land and the added value of the production depends on the practised agricultural policy. The indexes have to be modified taking into account the yield per hectare and the inputs from other production sectors. These comprise the various agricultural chemicals and the consumption of energy, which also crucially depend on the area of cultivated land. All material flows should be quantified as tons. However, in the present case study the energy consumption is expressed as terajoules, because internationally coherent conversion factors of the different forms of energy have not yet been determined (Juutinen 1999a).

\section{Material flows of the Finnish agriculture in 1970-1997}

The present level and development trends in use of natural resources are described as a time series extending from 1970 to 1997 . The main data source for the plant production in Finland are the statistics of Ministry of Agriculture and Forestry. Yearbook of Farm Statistics has been published in present form since 1983 (MMM 19831997) Supplementary information is provided by the register of garden enterprises (MMM 1998). The TMR of the agricultural sector comprises also the catches of hunting and fishing, picking of the wild berries and mushrooms and the reindeer husbandry, (RKTL 1993, 1997, METLA 1997, unpublished data of the Association of Reindeer Herding Co-operatives). The existence of these resources does not require human measures and therefore, they are primary inputs from nature. In order to avoid double counting, the domestic animal production, the fur animals' farming and the aquaculture are not included. These sectors are based on the feed feeding, whereby the primary inputs are refined into a different form. For the non-food items conversion factors have to be used, as the production is given as the area or as numbers of pieces. The official statistics on annual production volumes do not cover the production for private household use. This is estimated by the Statistics of Finland every fifth year and, as regards to fishing, by the Finnish Game and Fisheries Research Institute (RKTL 1993, 1997) every other year. Together the non-food and non-profitable production comprise about $2 \%$ of the total production. In practice, the reliability of the data is as good as that of the official statistics.

Over $90 \%$ of the farmers in Finland are joined within the environmental support system. This requires that the use of agrochemicals is recorded within the cultivation plan, the realisation of which is followed by the Ministry of Agriculture and Forestry. The procedure is similar as the mandatory book keeping of nutrients in several other European countries (OECD 1999). However, in Finland the actual use of agrochemicals has so far not been compiled at the national level. The data used in this study are based on volumes sold each year, and these are accurately known. The data sources are the statistics of Kemira Agro Ltd. (unpublished), of the Lime Association (unpublished) and the statistics of the Plant Production Inspection Centre (data on publications available on request from the author). Data on energy consumption are from Statistics of Finland and supplied by A. Juutinen, (personal communication) and those on import are from the official statistics of Board of Customs and compiled by Juutinen (1999b).

\section{Results}

The data on the direct material inputs and on the hidden flows of agriculture and related production sectors in Finland are summarised in the Appendix. The direct material inputs are nowadays about 12-13 millions tons, and the TMR excluding water and air amounts to about 30 millions tons or about 6 tons per capita per year (Fig. 2). From the DMI roughly 50 per cent is 


\section{AGRICULTURAL AND FOOD SCIENCE IN FINLAND}

Vol. 8 (1999): 393-410.

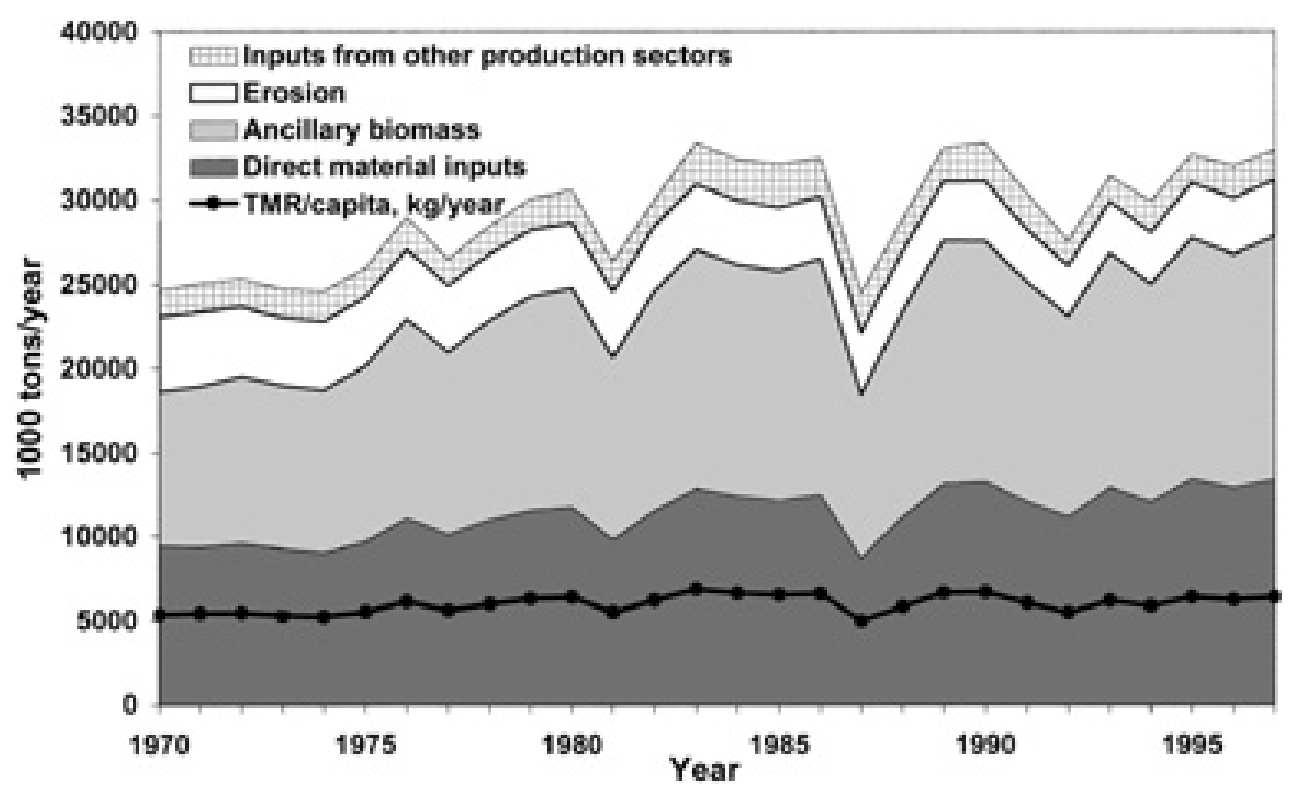

Fig. 2. The total material requirement (TMR) and the TMR/capita of agriculture and related production sectors in Finland in 1970-1997. The direct material inputs comprise the plant production, catches from fishing and hunting, production of reindeer husbandry and gathering from the wild. The commercial soil fertilisers, lime, biocides and growth regulators are included within the inputs from other production sectors. Energy consumption is not accounted for in the figure.

hay, silage and other feed materials (Fig. 3). Because majority of the domestic cereal production is also used for animal feeding, the animal feed stuffs comprise about 70 per cent of the plant production.

The mutual proportions of the various cereals, barley, oats, wheat and rye have remained remarkably constant from the 1970's up to these days, even though the total production of cereals has increased by $25-30 \%$. The cereals and the feed together comprise about $80 \%$ of the plant production in Finland. The rest consists of sugar beet $(10 \%)$, potatoes $(6 \%)$, and all other products, including the greenhouse and open air vegetables, apples, berries, the non-food products and the gathering from the wild. In the beginning of the 1970's, the potatoes comprised about $15 \%$ of the plant production. The share has, however, gradually diminished until the early 1990's. Then the production reached the level of $6-7 \%$, to which it seems to have been established. Correspondingly, the production of sugar beet and of the aggregated group of miscellaneous products has doubled during the same time period.

The relative proportions of the miscellaneous group are shown in Fig. 4. Among apples and berries, about one half is wild berries and the other half is garden products. The major part (70-80\%) of these never enters the markets, but is used in private households. However, considering all direct inputs, the non-profitable production has decreased from about $5 \%$ at the beginning of the 1970's to under $2 \%$ in the 1990's (Risku-Norja 1999).

The share of the hidden flows from the total material requirement is about 60 per cent. From the hidden flows the ancillary biomass and the estimated total erosion comprise together about 90\% (Fig. 2). These hidden flow factors are, 


\section{AGRICULTURAL AND FOOD SCIENCE IN FINLAND}

Risku-Norja, H. The total material requirement -concept applied to agriculture

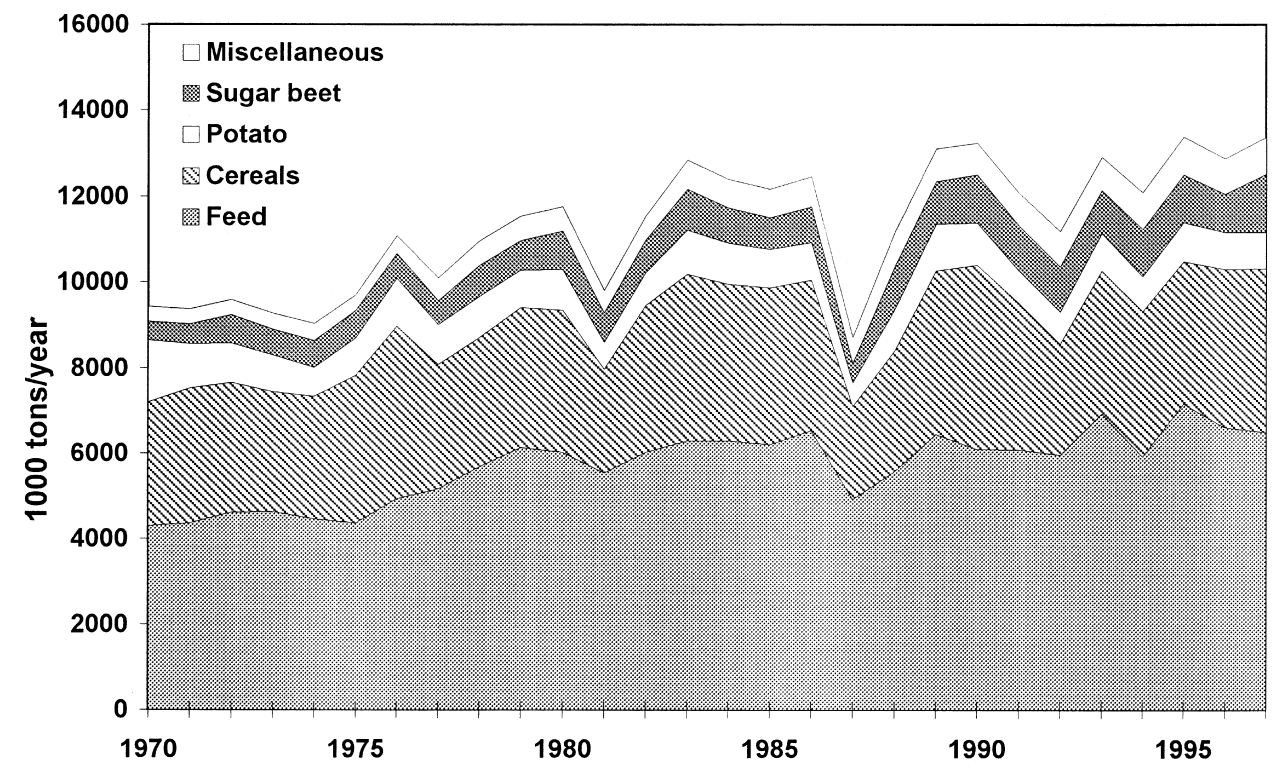

Fig. 3. The volume of the direct material inputs and the share of the cereals, feed stuffs, potatoes, sugar beat and aggregated miscellaneous products from the total volume of the direct material inputs in Finland in 1970-1997.

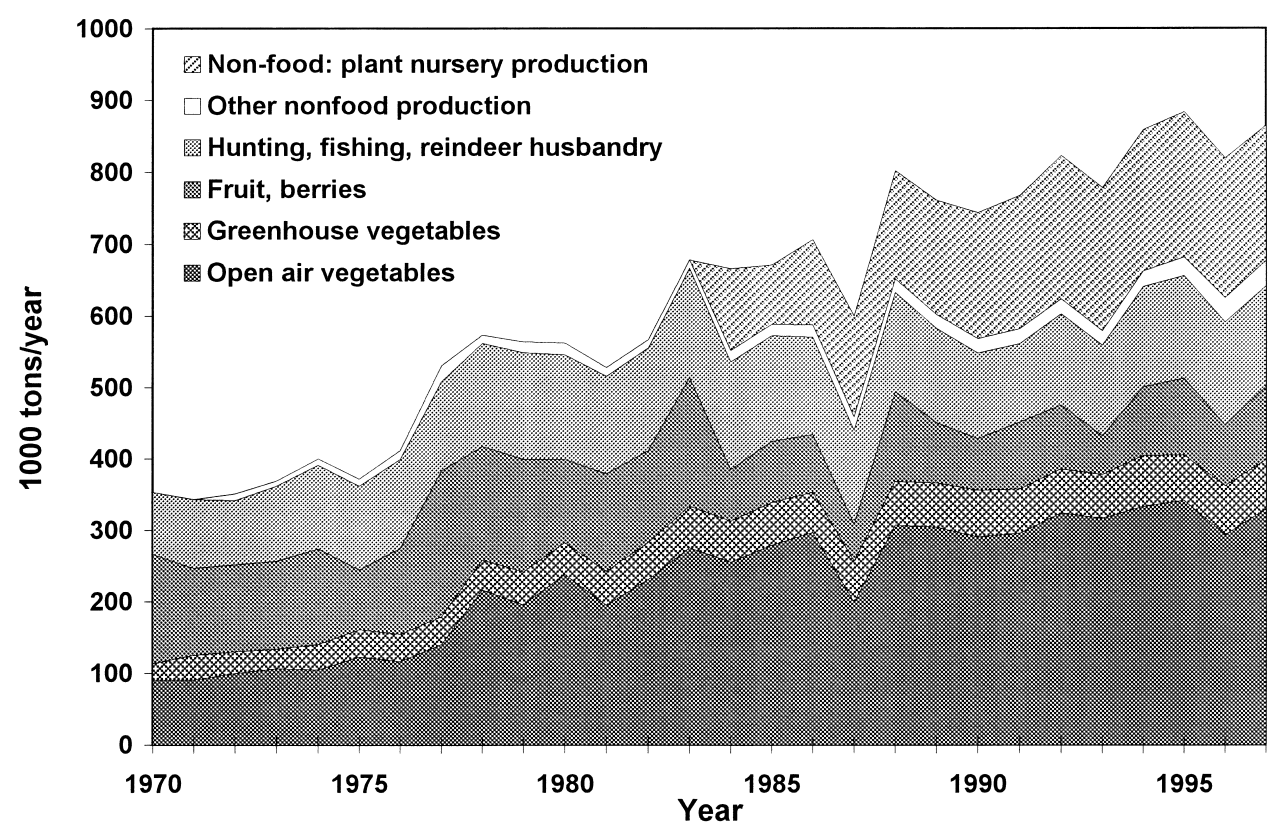

Fig. 4. The proportions of the various products included within the aggregated miscellaneous group in Finland in 1970-1997. 


\section{AGRICULTURAL AND FOOD SCIENCE IN FINLAND}

Vol. 8 (1999): 393-410.

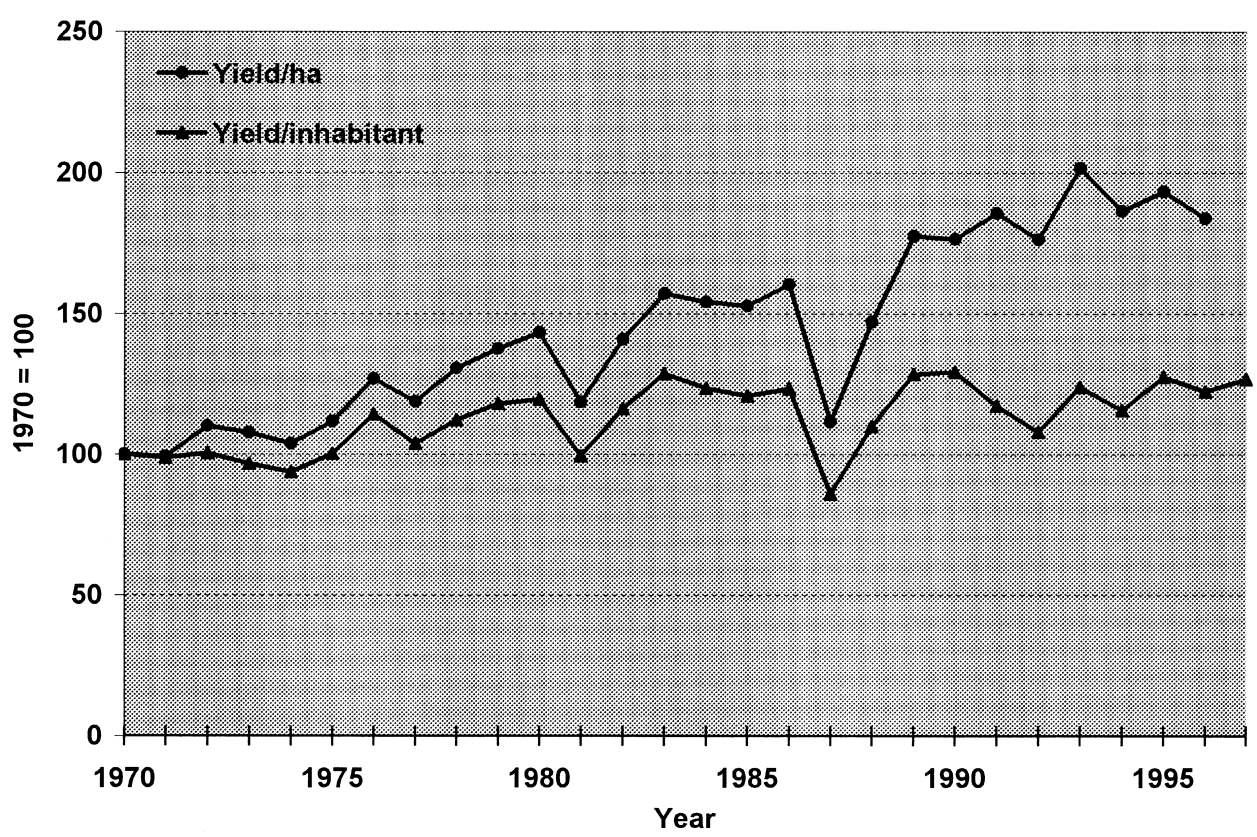

Fig. 5. The relative changes in the volume of agricultural production per capita and per hectare in Finland in 1970-1997 compared to those in 1970.

however, calculatory, because the estimation is based on the amount of plant production and on the area of cultivated land (Risku-Norja 1999). Changing the conversion factors, the TMR could be reduced, but sustainable agriculture is not promoted with calculatory methods. Besides, the erosion in Finland is of minor importance and creates problems only occasionally and very locally (Mansikkaniemi 1982, Peltonen 1996). Ancillary biomass, on the other hand, is tilled back into the soil and it also improves the quality of agricultural land. Therefore, the disadvantages caused by these hidden flows are negligible. In attempts to reduce the material flows, the attention has to be focused on the remaining $10 \%$ of the hidden flows, i.e. the agricultural chemicals and on the consumption of energy, as well as on the food consumption patterns and on the ways of production.

During the examined time period, the agricultural production has markedly intensified: yields per hectare have nearly doubled and even the per capita production has increased about $25 \%$ (Fig. 5). The intensification of agriculture has, however, been very energy-intensive because, at the same time, the consumption of energy has increased about $70 \%$, from 11 terajoules in the 1970 to about 18 terajoules per 1000 hectares cultivated area by the beginning of the 1990's. Since then the energy consumption appears to have stabilised at that level. The trends in use of the commercial soil fertilisers, biocides and growth regulators are similar: the yields per hectare have increased at the same pace as the use of the agricultural chemicals as far as to the end of the 1980's. In the 1990's the use of the agrochemicals has been drastically reduced, although the obtained level in the yields per hectare has been maintained. Thus, the trends in the amount of production and in use of agrochemicals per area have clearly separated indicating sprouting ecoefficiency in agriculture (Fig. 6).

The ecoefficiency can be expressed as simple ratios $(\mathrm{DMI}=$ direct material input $)$ : 


\section{AGRICULTURAL AND FOOD SCIENCE IN FINLAND}

Risku-Norja, H. The total material requirement -concept applied to agriculture

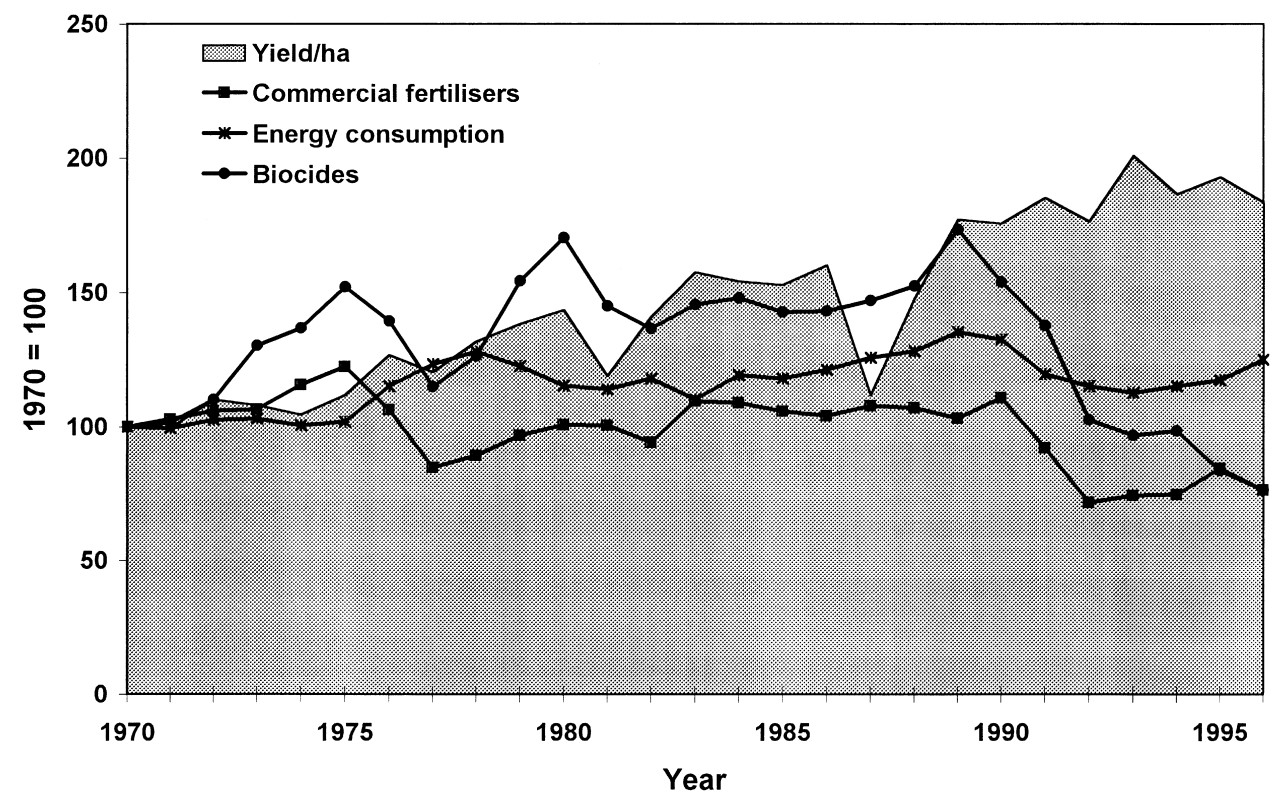

Fig. 6. The relative changes in energy consumption and in use of commercial soil fertilisers and biocides as well as in yields per hectare in 1970-1997 in Finland compared to the level in 1970.

\begin{tabular}{|c|c|}
\hline $\begin{array}{l}\sum \operatorname{DMI}(19 \mathrm{xx}) \\
\operatorname{cla}(19 \mathrm{xx})\end{array}$ & $\frac{\text { energy consumption }(19 x x)}{\operatorname{cla}(19 x x)}$ \\
\hline $\begin{array}{l}\sum \operatorname{DMI}(19 \mathrm{xx}) \\
\operatorname{cla}(19 \mathrm{xx})\end{array}$ & $\frac{\text { use of fertilisers }(19 x x)}{\operatorname{cla}(19 x x)}$ \\
\hline$\frac{\sum \operatorname{DMI}(19 x x)}{\operatorname{cla}(19 x x)}:$ & $\frac{\text { use of biocides }(19 x x)}{\operatorname{cla}(19 x x)}$ \\
\hline
\end{tabular}

The growth of the ratios as the function of the time shows that agricultural production is developing towards increasing sustainability. A clear comprehension of the tempo of the change is obtained when the ratio of a given year is compared to that of the base year:

$\left(\sum_{1995} /\right.$ use of biocides $\left.{ }_{1995}\right) /\left(\sum \mathrm{DMI}_{1970} /\right.$ use of biocides $\left._{1970}\right)$.

The factor obtained shows directly the change in material intensity compared to the base level. In Table 1 the indexes and the factors have been calculated from the data given

$$
\begin{aligned}
& =\sum \mathrm{DMI}_{19 \mathrm{xx}} / \text { energy consumption }{ }_{19 \mathrm{xx}} \\
& =\sum \mathrm{DMI}_{19 \mathrm{xx}} / \text { use of fertilisers }{ }_{19 \mathrm{xx}} \\
& =\sum \mathrm{DMI}_{19 \mathrm{xx}} / \text { use of biocides } \\
& \text { cla }{ }_{19 \mathrm{xx}}=\text { cultivated land area }
\end{aligned}
$$

in the Appendix. The base level is the year 1970 . The table shows that as to the biocides and commercial fertilisers the ecoefficiency has improved by a factor of 1.7 , but as to energy consumption only by 1.2 . Up to the beginning of the 1990's the changes have been negligible or the ecoefficiency has even degraded. The improvements have taken place in the 1990's. The factors give an idea of how much the production has to be increased or the use of agrochemicals or energy has to be decreased in order to achieve the defined goals within a given period of time. If the improvement would take place 
Vol. 8 (1999): 393-410.

Table 1. The indexes based on the material flows of the agriculture and the factors expressing the change in material intensity since 1970 .

\begin{tabular}{|c|c|c|c|c|c|c|}
\hline & & IDEX & & & СТO & \\
\hline & A & B & $\mathrm{C}$ & I & II & III \\
\hline 1970 & 8.2 & 3.4 & 34.0 & 1.0 & 1.0 & 1.0 \\
\hline 1971 & 7.9 & 3.4 & 33.9 & 1.0 & 1.0 & 1.0 \\
\hline 1972 & 7.8 & 3.2 & 33.7 & 1.0 & 0.9 & 1.0 \\
\hline 1973 & 7.6 & 2.6 & 32.4 & 0.9 & 0.8 & 1.0 \\
\hline 1974 & 6.8 & 2.4 & 32.4 & 0.8 & 0.7 & 0.9 \\
\hline 1975 & 6.9 & 2.3 & 34.3 & 0.8 & 0.7 & 1.0 \\
\hline 1976 & 9.0 & 2.9 & 34.7 & 1.1 & 0.8 & 1.0 \\
\hline 1977 & 10.3 & 3.2 & 29.5 & 1.3 & 0.9 & 0.9 \\
\hline 1978 & 10.6 & 3.2 & 30.9 & 1.3 & 0.9 & 0.9 \\
\hline 1979 & 10.3 & 2.7 & 33.9 & 1.3 & 0.8 & 1.0 \\
\hline 1980 & 10.1 & 2.5 & 36.7 & 1.2 & 0.7 & 1.1 \\
\hline 1981 & 8.5 & 2.5 & 31.0 & 1.0 & 0.7 & 0.9 \\
\hline 1982 & 10.6 & 3.1 & 35.3 & 1.3 & 0.9 & 1.0 \\
\hline 1983 & 10.2 & 3.2 & 42.0 & 1.2 & 0.9 & 1.2 \\
\hline 1984 & 9.9 & 3.1 & 37.5 & 1.2 & 0.9 & 1.1 \\
\hline 1985 & 10.0 & 3.1 & 37.2 & 1.2 & 0.9 & 1.1 \\
\hline 1986 & 10.4 & 3.2 & 37.0 & 1.3 & 0.9 & 1.1 \\
\hline 1987 & 7.0 & 2.2 & 25.0 & 0.9 & 0.6 & 0.7 \\
\hline 1988 & 9.0 & 2.7 & 31.4 & 1.1 & 0.8 & 0.9 \\
\hline 1989 & 11.0 & 2.8 & 34.9 & 1.3 & 0.8 & 1.0 \\
\hline 1990 & 10.4 & 3.1 & 36.0 & 1.3 & 0.9 & 1.1 \\
\hline 1991 & 11.4 & 3.2 & 36.4 & 1.4 & 0.9 & 1.1 \\
\hline 1992 & 13.5 & 4.0 & 35.0 & 1.6 & 1.2 & 1.0 \\
\hline 1993 & 15.1 & 4.9 & 41.3 & 1.8 & 1.4 & 1.2 \\
\hline 1994 & 14.0 & 4.5 & 37.9 & 1.7 & 1.3 & 1.1 \\
\hline 1995 & 13.8 & 5.8 & 41.1 & 1.7 & 1.7 & 1.2 \\
\hline 1996 & 14.6 & 6.2 & 37.1 & 1.8 & 1.8 & 1.1 \\
\hline 1997 & 16.2 & 5.9 & - & 2.0 & 1.7 & - \\
\hline
\end{tabular}

$\mathrm{A}=$ direct material input $(\mathrm{DMI}) / \mathrm{use}$ of commercial fertilisers, $\mathrm{B}=0.001 * \mathrm{DMI} / \mathrm{use}$ of biocides $\mathrm{C}=100 *$ DMI/energy consumption, $\mathrm{I}=$ commercial fertilisers, $\mathrm{II}=$ biocides, $\mathrm{III}=$ energy consumption.

at the same pace as within the past 25 years, as to the biocides and fertilisers, the Factor 4 goals would be achieved within about 60 years, but improving energy efficiency by a factor of 4 would require 90 years. If, on the other hand, the ecoefficiency of the agricultural production would improve at the same pace as in this decade, the factor 4 goals for biocides, fertilisers and energy would be achieved in 12, 15 and 25 years, respectively. The approach may, thus, be helpful in setting realistic goals to improve ecoefficiency and in follow-up the realisation of the set goals.

\section{Discussion}

\section{The future perspective: possibilities to increase the resource efficiency of agricultural production in Finland}

Due to above all more accurately targeted cultivation measures, the use of the chemicals has already been successfully and markedly cut down. The contributing factors to the positive development are the well functioning weather 


\section{AGRICULTURAL AND FOOD SCIENCE IN FINLAND}

\section{Risku-Norja, H. The total material requirement -concept applied to agriculture}

and pest prediction services as well as the growing demand and utilisation of the soil fertility analyses. The soil fertilisation recommendations published by the Finnish Soil Fertility Service have been continuously checked downwards since the 1970's (Yli-Halla personal communication). The reduction in use of the biocides is partly caused by the increasing use of the socalled gramherbicides starting in the late 1980's. The use of agrochemicals is also controlled by the conditions of the environmental support and price policy. The environmental awareness and the educational level of the farmers have also improved, availability of the information on research dealing with the environmental side effects of agriculture has increased and this information is better utilised.

Agriculture is an important sector of the society and the high degree of self-sufficiency of production should be the aim also in future (Ympäristöministeriö 1999). Reducing the agricultural TMR is limited by the fact, that the human being requires certain energy intake to survive. However, in order to promote sustainable development, the ecoefficiency of the production must - and it can - be increased. The precondition is to produce more out of less and, at the same time, lower the environmental load. This requires that, while reducing the environmental impact, the yields per hectare increase or the volume of the hidden flows decreases or both. In practice it is, however, impossible to distinguish these goals from each other: the measures aimed at reaching any one of the goals may promote or prohibit reaching the others. In addition, trade and the consumers have various requirements. These concern not only the prise, quality and availability of the products, but also the environmental aspects and the ethics of the production. These requirements may affect the goals of increasing ecoefficiency in a conflicting way.

Generally, an effective way of reducing material throughput is to cut down the volume of the hidden flows. In contrast to the national TMR:s, where the recycled materials comprise only a fraction of the total material requirement, recycling in agriculture is quite effective already.
This is because in agriculture about $70 \%$ of the hidden flows is tied in the ancillary biomass and major part of this is tilled back into the soil and never enters the econosphere. Ancillary biomass should, therefore, not be accounted for. Excluding the ancillary biomass from the TMR apparently limits the ways to reduce the agricultural TMR. However, sustainability is not promoted with calculatory tricks, but the improvements have to be made starting from the prevailing, true situation.

The use of various chemicals and the energy consumption comprise only few per cent of the agricultural TMR, but they are key factors when assessing the sustainability of the agriculture. The aim of the so-called targeted cultivation is an accurate use of biocides and soil fertilisers in various parts of the field plots. The prerequisite is the synchronisation of the observation and prevention measures (Tyystjärvi et al. 1998). At present, this is not possible, but requires technological innovations. With targeted cultivation a considerable reduction in use of agrochemicals and, therefore, also a relief in the environmental load caused by agriculture is expected. Combined with marked substitution of the fossil energy with renewable energy sources, renewal of agricultural machinery, co-operative or commercial use of the machinery, development of the cultivation methods, the changes in the production structure as well as accurate targeting and timing of the cultivation measures resource efficiency can be markedly improved.

Sufficient and healthy nutritional level can be maintained or, in some cases, obtained with various types of diets and with food derived from various sources. Food is strictly a non-reusable commodity, and the behaviour of the consumers has, therefore, direct and profound influence on the material intensity of the food production: over the past 30 years the per capita plant production has increased by about $25 \%$. This is at least partly explained by the fact, that during the same time period the consumption of meat products has markedly increased (MMM 1997), which requires corresponding growth in production of animal feed. At the moment about $70 \%$ 
Vol. 8 (1999): 393-410.

of the agricultural production in Finland is feed for domestic animals. Changing diets towards more vegetarian direction would, no doubt, reduce the material flows of the agriculture. This is because a considerably larger part of the solar energy bound by the vegetation could be used directly for human nutrition thus lowering the demand for feed production. If only the total volume of plant production was to be considered, the yields per hectare could be increased by a factor of ten by shifting the accent of cultivation from cereals and feed to root crops and other products. Affecting material flows via diet changes is, however, not that straightforward, since large part of the cultivated land in Finland is suitable only for production of hay and silage. The effects of these aspects on material intensity of the food production are worth thorough research.

The aim of plant breeding is to increase the yields per hectare by developing high-yielding and resistant varieties adapted for local circumstances. The proliferation of plant production by plant breeding took place already in the 1930's, when the results of the hybridisation breeding were introduced in a large scale. After that the increase in plant production due to plant breeding has slowed down, and nowadays it is estimated to be about $0.5-1 \%$ in average (Mela 1999, personal communication). The emphasis in plant breeding is also shifting from quantity towards quality breeding. In near future, marked increase in yields by introduction of new varieties is, therefore, not expected. Another way would be to affect the efficiency of photosynthesis, but so far there has been little success in this.

When the agricultural TMR is discussed, one of the key questions is the ecoefficiency of the organic production. The problem is many-facetted: compared to conventional farming, the yields per hectare are up to three times lower, and the more extensive cultivation means also corresponding increase in energy consumption (Voutilainen 1999, personal communication). The labour intensive nature of organig farming may, however, partly compensate the high energy demand. Production, refinement and deliv- ery of organic products are poorly organised in Finland and therefore, the organic production chain from field to consumers demands additional energy for transports. On the other hand, direct environmental benefits are gained, because commercial fertilisers and biocides are not used. Neither is the environmental load restricted to the direct impact of the agrochemicals. Their ecological rucksack, i.e. the natural resources required for their production and transportation, must also be accounted for. An additional point of view is that even the organic farming, in spite of its naturality, is based on monocultures. The extensive cultivation deprives room from the natural ecosystems.

\section{Needs for further development of the MFA methods for agriculture}

The aim of environmental policy measures is to reduce discharges and substantially cut down the consumption of natural resources. This can be accomplished by reducing material flows at the input side and simultaneously treating the environmental problems caused by the economic activity. For this purpose, MFA is a powerful tool, which supplements the methods already in practice. In recent years, the MFA methodology has been under vivid development both on national and regional scale as means of assessing the extent of exploitation of natural resources (ConAccount 1998). It has obtained increasing relevance as an additional indicator of sustainability and as a policy tool (Jänicke 1997, Bringe$\mathrm{zu}$ and Moll 1998). In setting common environmental goals, there is an urgent need of internationally comparable data on gross national material flows as well as on the material throughput in various production sectors of the economy. In this study the TMR-concept of the MFA has been applied to agriculture and the feasibility of the approach has been shown. However, the most commonly used TMR-based indicators are not always applicable as such within the agricultural sector, but specific MFA methods need 


\section{AGRICULTURAL AND FOOD SCIENCE IN FINLAND}

\section{Risku-Norja, H. The total material requirement -concept applied to agriculture}

to be developed. Some of the factors contributing to this are:

1) The total volume of the agricultural production as well as the energy consumption and the use of agrochemicals are crucially dependent on the area of cultivated land. This should be accounted for. The areal aspect is included within the suggested three general indexes, $\Sigma \mathrm{DMI}_{19 \mathrm{xx}}$ ' energy consumption ${ }_{19 x \mathrm{xx}}, \sum \mathrm{DMI}_{19 \mathrm{xx}} / \mathrm{use}$ of biocides $_{19 \mathrm{xx}}$ and $\Sigma \mathrm{DMI}_{19_{\mathrm{xx}}}$ /use of commercial fertilisers $_{19 x \mathrm{x}}$. These and similar indexes have to be developed further and their validity should be considered thoroughly.

2) Ancillary biomass makes up the major part of the hidden flows of agriculture. Through the volume and the positive effects on soil, the ancillary biomass actually is a form of negative hidden flow, and it should be excluded from the TMR

3) The share of the added value of agriculture from the gross national product in Finland is only 2-3\% (Mäenpää, I., personal communication), and the TMR/GNP index actually shows only the variation in production volumes caused by the conditions of the annual growing season. In addition, because the production is supported in various ways and in some countries even the prices of the products are regulated, value added is largely dictated by the agricultural policy. The production supports and the price regulations are measures to keep the farmers' income at a sufficient and reasonably stable level. Therefore, the economical sustainability of agriculture cannot be assessed with TMR/GNP or TMR/agricultural income indexes. The development of an objective and reliable nominator is problematic and requires further work.

4) So far, the share of the import from the agricultural TMR cannot be assessed. Imported raw materials are only of the order of one per cent of it, and the share has remained low during the whole examination period. However, major part of the imported agricultural products are processed goods, and the hidden flows associated with them have not yet been estimated (Juutinen, A., personal communication). The ecological rucksack of the imported agricultural goods should be accounted for, before the TMR of the Finnish agriculture can be reliably quantified.

5) When the TMR:s in various sectors of economic life are considered, the inputs from other production sectors must be accounted for. In agriculture these include the energy, agrochemicals and the machinery. In order to properly allocate the share of agriculture from the natural resources required for these products, their ecological rucksacks should be known. The MFA and LCA approaches thus overlap, and the MFA method needs to be supplemented with LCAdata. A convenient way to combine the two methods awaits to be developed.

6) The consumption of energy is expressed as total energy. A prerequisite for promoting sustainability is to increase the share of the renewable energy with the expense of the fossil energy. The proportion of the various energy sources should be distinguished. In addition, all material flows should be quantified as tons, and the energy consumption expressed as terajoules should be converted to tons.

Acknowledgements. I thank the research fellows at the agricultural Research Centre of Finland, Resource Management Research for many lively discussions and exchange of the ideas. Special thanks to professor Sirpa Kurppa for the critics and the valuable comments she made while reading the mansucript, and to Dr. Markku Yli-Halla for encourgement, discussions and guidance. Special thanks for the practical help also to Mr. Antti Kallio and Mr. Leif Söderlund and to Ms. Kaarina Grek. 


\section{References}

Adriaanse, A., Bringezu, S., Hammond, A., Moriguchi, Y., Rodenburg, E., Rogich, D. \& Schütz, H. 1997. Resource flows: the material basis of industrial economies. World Resources Institute. $63 \mathrm{p}$.

Ayers, R.U. 1989a. Industrial metabolism and global change. Industrial Social Science Journal 121: 363373.

- 1989b. Industrial metabolism In: Ausubel, J.H \& Sladovich, E.H. (eds.). Technology \& Environment. National Academy Press, Washington D.C. p. 23-49.

- 1997. Industrial metabolism: work in progress. INSEAD Working Paper 97/09/EPS, Fontainebleau, France. $36 \mathrm{p}$.

- \& Kneese, A.V. 1969. Production, consumption and externalities. American Economic Review 59: 282297.

Baccini, P. \& Brunner, P.H. 1991. Metabolism of the anthroposphere. Berlin, Springer Verlag. 1991. 305 p.

Beltrán, D.J. 1997. A possible role of material flow analysis within the European environmental reporting system - changing course in environmental information. In: Bringezu, S. et al. (eds.). Analysis for action: support policy towards sustainability by material flow accounting. Proceedings of the ConAccount conference 11-12 September 1997. Wuppertal Special 6: $16-27$.

Boulding, K. 1966. The economics of the coming spaceship Earth. In: Jarret, H. (ed. ). Environmental quality in a growing economy. Resources for the future. John Hopkins University Press, Baltimore. p. 3-14.

Bringezu, S. 1997. Comparison of the material basis of industrial economies. In: Bringezu, S. et al. (eds.). Analysis for action: support policy towards sustainability by material flow accounting. Proceedings of the ConAccount conference 11-12 September 1997. Wuppertal Special 6: 57-66.

- \& Moll, S. 1998. Coordination of regional and national material flow accounting for environmental sustainability - ConAccount. In: Bringezu, S. et al. (eds). The ConAccount Agenda: The Concerted Action on Material Flow Analysis and its Research \& Development Agenda. Wuppertal Special 8: 8-17.

Burström, F. 1998. Municipal materials accounting and environmental management. TRITA-KET-IM 1998:5. Licentiate thesis, Royal Institute of Technology, Stockholm. p. 68.

-, Brandt, N. \& Frostell, B. 1998. Analysing material flows to improve local environmental management: Nitrogen metabolism of a Swedish rural municipality. In: Burström, F. Municipal materials accounting and environmental management. TRITA-KET-IM 1998: 5. Licenciate thesis, Royal Institute of Technology, Stockholm, Paper II. 37 p.

- , Brandt, N., Frostell, B. \& Mohlander, U. 1997. Material flow accounting and information for environmental policies in the city of Stockholm. In: Bringezu, S. et al. (eds.). Analysis for action: support policy towards sustainability by material flow accounting. Proceedings of the ConAccount conference 11-12 Sep- tember 1997. Wuppertal Special 6: 136-145.

Carley, M. \& Spapens, P. 1998. Sharing the world. Sustainable living and global equity in the 21st century. Earthscan. 224 p.

ConAccount 1998. Research and development agenda fort material flow analysis. Cited: 13 September 1999. Updated: 11 December 1998. Available from Internet http://www.wuppertal institut.de/Projekte/ConAccount/agenda.html.

Daly, H. 1968. On economics as a life science. The Journal of Political Economy 76: 392-406.

deMarco, O., Lagioia, G. \& Pizzoli Mazzacane, E. 1999. Material flow analysis of the Italian economy. Preliminary results. In: Kleijn, R. et al. (eds.). Ecologizing societal metabolism. Designing scenarios for sustainable materials management. November $21^{\text {st }} 1998$, Amsterdam, The Netherlands. Leiden University, Centre of Environmental Science Report 148: 3137.

ECOEFF 1999. Eco-efficient Finland. Total material requirement and the possibilities to reduce it in Finland. Available from the Internet: http://thule.oulu.fi/ ecoef/. Updated 22 September 1999, cited 25 September 1999.

Erkman, S. 1997. Industrial ecology: an historical view. Journal of Cleaner Production 5, 1-2 : 1-10.

Evans, R. 1995. Some methods of directly assessing water erosion of cultivated land. Progress in Physical Geography 19, 1: 115-129.

Factor 10 Club 1997. Carnoules statement to government and business leaders. A ten-fold leap in energy and resource efficiency. Cited: 14 September 1999. Updated: 23 March 1998. Available from Internet: http:/ /www.baltic-region.net/science/factor10.htm.

Frostell, B., Brandt, N. \& Burström, F. 1998. The ComBox model: A conceptual approach to an improved environmental monitoring in the local community. In: Burström, F. Municipal materials accounting and environmental management. TRITA-KET-IM 1998: 5. Licenciate thesis, Royal Institute of Technology, Stockholm, Paper I. $18 \mathrm{p}$.

Hinterberger, F. 1994. Biological, cultural and economic evolution and the economy/ecology Relationship. In: Straaten, J.V.D. et al. (eds.). Towards sustainable development - concepts, methods and policy. Island Press, Washington DC. p. 57-81.

- , Luks, F. \& Schmidt-Bleek, F. 1997. Material flows vs. "natural capital", what makes an economy sustainable? Ecological Economics 23: 1-14.

Hoffrén, J. 1998. Materiaalivirtatilinpito luonnonvarojen kokonaiskulutuksen seurantavälineenä. (Material flow accounting as a measure of the total consumption of natural resources.) Ympäristöministeriö. (Ministry of the Environment) Suomen ympäristö 257. $52 \mathrm{p}$.

- 1999. Talous hyvinvoinnin ja ympäristöhaittojen tuottajana - Suomen ekotehokkuden mittaaminen. Research reports 226, Statistics Finland. 154 p.

Hüttler, W., Schandl, H., \& Weisz, H. 1999. Are industrial 


\section{AGRICULTURAL AND FOOD SCIENCE IN FINLAND}

\section{Risku-Norja, H. The total material requirement -concept applied to agriculture}

economies on the path of dematerialization? Material flow accounts for Austria 1960-1996: indicators and international comparison. In: Kleijn, R. et al. (eds.) Ecologizing societal metabolism. Designing scenarios for sustainable materials management. November $21^{\text {st }} 1998$, Amsterdam, The Netherlands. Leiden University, Centre of Environmental Science Report 148: 23-30.

Höhn, B. 1997. Providing for the Future trough avoidance - a precondition for change in ecological structures. In: Bringezu, S. et al. (eds.). Analysis for action: support policy towards sustainability by material flow accounting. Proceedings of the ConAccount conference 11-12 September 1997. Wuppertal Special 6: 10-14.

Imeson, A.C. \& Kwaad, F.J.P. 1990. The response of tilled soils to wetting by rainfall and the dynamic character of soil erodobility. In: Boardman, J. et al. (eds). Soil erosion in agricultural land. John Wiley\&Sons, London. p. 121-136.

Jänicke, M. 1997. The role of MFA and resource management in national environmental policies. In: Bringezu, S. et al. (eds.). Analysis for action: Support policy towards sustainability by material flow accounting. Proceedings of the ConAccount conference 11-12 September 1997. Wuppertal Special 6: 68-72.

Juutinen, A. 1999a. Energiamateriaalien virrat. Interim report of the ECOEF-project, Thule Institute, University of Oulu. Available from the Internet: http:// thule.oulu.fi/ecoef/. Updated 22 September 1999, cited 25 September 1999. 19 p.

- 1999b. Tuonnin materiaalivirrat. Interim report of the ECOEF-project, Thule Institute, University of Oulu. Available from the Internet: http://thule.oulu.fi/ecoef/. Updated 22 September 1999, cited 25 September 1999. 20 p.

- \& Mäenpää, I. 1999. Time series of the total material requirement of the Finnish economy. Summary. Interim report of the ECOEF-project, Thule Institute, University of Oulu. Available from the Internet: http:/ /thule.oulu.fi/ecoef/. Updated 22 September 1999, cited 25 September 1999. 17 p.

KTM 1998. Ekotehokkuus ja factor-ajattelu. (Eco-efficiency and Factors). Kauppa- ja teollisuusministeriön Työryhmä- ja toimikuntaraportteja (Ad-hoc committee reports, Ministry of Trade and Industry) 1/1998. $45 \mathrm{p}$.

Lettenmeier, M. 1998. MIPS kertoo ympäristön kulutuksesta. Ympäristö ja terveys 6: 60-63.

Lindqvist, A. \& Eklund, M. 1999. Substance flow analysis of cadmium in society's waste. In: Kleijn, R. et al. (eds.). Ecologizing societal metabolism. Designing scenarios for sustainable materials management. November $21^{\text {st }} 1998$, Amsterdam, The Netherlands. Leiden University, Centre of Environmental Science Report 148: 183-187.

Lovins, A., Weizsäcker, E.V. \& Lovins, H. 1997. Factor 4. Allen \& Unwin. $322 \mathrm{p}$.

MAcTEmPo 1997. Materials accounting as a tool for decision making in environmental policy (MAc TEMPo). EC Environment and Climate Research Programme (1994-1998). Research Theme 4 - Human Dimen- sion of Environmental Change. Contract no.: ENV4CT96-0230. Cited: 14 September. Updated: 24 February. Available from Internet: http:// awsunix.tuwien.ac.at/mactempo/mactempo.htm.

Mansikkaniemi, H. 1982. Soil erosion in areas of intensive cultivation in southwestern Finland. Fennia 160, 2: 225-276.

Meadows, D.H., Meadows, D.L., Randers, J. \& Behrens, C.W. 1972. The limits to growth. University Press, New York. 205 p.

METLA 1997. Metsätilastollinen vuosikirja 1997. Metsäntutkimuslaitos. (Finnish Statistical Yearbook of Forestry 1997, Finish Forest Research Institute) SVT Maa- ja metsätalous 1997:4. 348 p.

MMM 1983-1997. Yearbook of farm statistics (annual issues). Information Centre of the Ministry of Agriculture and Forestry, Helsinki.

- 1997. Ravintotase 1996 ja ravintotaseet 1990-1995. Maa- ja metsätalousministeriön tietopalvelukeskus (Balance Sheets for Food Commodities 1996 (preliminary) and 1990-1995. Information Centre of the Ministry of Agriculture and Forestry) Helsinki. 108 p.

- 1998. Puutarhayritysrekisteri 1997. Maa- ja metsätalousministeriön tietopalvelukeskus (Information Centre of the Ministry of Agriculture and Forestry) Helsinki. $108 \mathrm{p}$.

OECD 1997. Ecoefficiency: decoupling economic growth from environmental damage. Environment Directorate, Environmental Policy committee. ENV/EPOC/ PPC (97) 8.

- 1999. Eco-efficiency: The potentials and limitations of implementing the Factor 4 Strategy on the production and consumption of food. A swedish case study. Preliminary version for the workshop "Eco-efficiency: From Principle to practice" 15-18 March in Sydney. 63 p.

Peltonen, S. 1996. Maaperäeroosio ja pintaveden laatu Unajanjoen valuma-alueen alaosassa LounaisSuomessa. (Soil erosion and water quality in the lower part of the Unajanjoki drainage basin, southwestern Finland). Terra 108, 3: 143-159.

Repetto, R., Dale, R., Faeth, P. \& Austin, D. 1996. Has environmental protection really reduced productivity growth? We need unbiased measures. World Resources Institute, Washington DC. 46 p.

Risku-Norja, H. 1999. Luonnonvarojen kokonaiskäyttö Suomen maataloudessa 1970-1997. Interim report of the ECOEF-project, Agricultural Research Centre, Natural Resources Management. Available from the Internet: http://thule.oulu.fi/ecoef/. Updated 22 September 1999, cited 25 September 1999. 35 p.

RKTL 1993. Kalatalous ajassa. Tilastoja ja tietoa kalastuksesta, kalanviljelystä ja kalakaupasta vuosina 1978-1992. Riista- ja kalatalouden tutkimuslaitos (Finnish Game and Fisheries Research Institute). SVT Ympäristö 1993:11. 138 p.

- 1997. Kalavirrat - Tietoa kalan tarjonnasta ja käytöstä. Riista- ja kalatalouden tutkimuslaitos (Finnish Game and Fisheries Research Institute ). SVT Ympäristö 1997: 13. 68 p.

Schmidt-Bleek, F. 1993. Wieviel Umwelt braucht der Mensh? MIPS - Das Mass für ökologischen Wirtschaften. Birkhäuser, Berlin. 302 p. 
Vol. 8 (1999): 393-410.

- 1998. Das MIPS-Konzept. Weniger Naturverbrauch - mehr Lebensqualität durch Faktor 10. Droemer Knaur, MÚnchen. 320 p.

- , Bringezu, S., Hinterberger, F., Liedtke, C., Malley, C., Ritthof, M., Spangenberg, J., Stiller, H., Tischner, U. \& Welfens, M.J. 1998. MAIA Einführung in die Materialintensitäts-Analyse nach dem MIPS-Konzept. Wuppertal Texte. Birkhäuser Verlag, Berlin. 120 p.

Schütz, H. \& Bringezu, S. 1998. Economy-wide material flow accounting (MFA). Technical Dokumentation. Wuppertal Institute. Division for Material Flows and Structural Change. MFA-Workshop 2-5 June 1998, Wiesbaden.

Spangenberg, H.J. 1995. Towards sustainable Europe. Wuppertal Institute for Climate, Environment, Energy. Friends of the Earth Europe. 240 p.

Spapens, P. 1998. Succesfully using resource use analysis in the policy debate: the sustainable Europe campaign of Friends of the Earth Europe. In: Bringezu, S. et al. (eds.). Analysis for action: support policy towards sustainability by material flow accounting. Proceedings of the ConAccount conference 11-12 September 1997. Wuppertal Special 6: 89-99.

Sörme, L. 1999. Inflow and accumulation of heavy metals in Stockholm, Sweden. In: Kleijn, R. et al. (eds.). Ecologizing societal metabolism. Designing scenarios for sustainable materials management. November $21^{\text {st }} 1998$, Amsterdam, The Netherlands. Leiden University, Centre of Environmental Science Report 148: 74-76.

Tyystjärvi, E., Keränen, M., Koski, A., Nevalainen, O. \& Aro, E.-M. 1998. Chlorofyll fluorescence can be used to identify plant species automatically. Proceedings of the $\mathrm{X}^{\text {th }}$ International Congress of Photosynthesis (in press).

UN 1995. Promoting sustainable agriculture and rural development. Report of the Commission on Sustainable Development on the Third Session (11-28 April 1995). Cited: 13 September 1999. Updated: 20 April 1999. Available from Internet: www.un.org/esa/sustdev/

Voet, E.V.D., Klejin, R., Oers, L.V., Heijungs, R., Huele, R. \& Mulder, P. 1995. Substance flows through the economy and environment of a region. Part I: Systems definition. Environmental Science \& Pollution Research 2: 89-96.

- , Klejin, R. \& Udo de Haes, H.A. 1996. Nitrogen pollution in the European Union: origins and proposed solutions. Environmental Conservation 23, 2: 120132.

- , Oers, L.V. \& Guinée, J.B. 1997. In: Bringezu, S. et al. (eds.). Analysis for action: Support policy towards sustainability by material flow accounting. Proceedings of the ConAccount conference 11-12 September 1997. Wuppertal Special 6: 119-129.

Wackernagel, M. \& Rees, W. 1996. Our ecological footprint. Reducing human impact on the Earth. New Society Publishers, Canada. 160 p.

WCED 1987. Our common future. Oxford University Press, Oxford. $400 \mathrm{p}$.

Weizsäcker, E.U.V., Lovins, A.B. \& Lovins, H.L. 1997. Doubling welfare, halving resource use. The New Report to the Club of Rome, London, Earthscan. $352 \mathrm{p}$.

Ympäristöministeriö 1998. Hallituksen kestävän kehityksen ohjelma. (Finnish Government's Programme for Sustainable Development). Suomen Ympäristö 254. $51 \mathrm{p}$.

- 1999. Itämeren alueen kestävän kehityksen ohjelma - Baltic 21.(An Agenda 21 for the Baltic Sea Region - Baltic 21, Ministry of Environment). Suomen Ympäristö 279. $51 \mathrm{p}$.

\title{
SELOSTUS
}

\section{Luonnonvarojen kokonaiskäyttö sovellettuna maatalouteen: esimerkki Suomesta}

\author{
Helmi Risku-Norja \\ Maatalouden tutkimuskeskus
}

Jatkuva tuotannon ja kulutuksen kasvu perustuvat energiaan ja luonnon raaka-aineisiin. Ihmisen taloudellisesta toiminnasta aiheutuu katkokseton materiaalivirta luonnosta antroposfäärin kautta takaisin luontoon, sillä kaikki ihmisen käyttämä aine on viime kädessä peräisin luonnosta ja kaikki myös päätyy ennen pitkää takaisin luontoon, usein muuttunees- sa ja luonnon kannalta hankalassa muodossa. Nykyiset tuotantotavat ovat nopeasti osoittautumasssa kestämättömiksi, sillä raaka-aineiden käyttöönoton yhteydessä siirretään ja muokataan valtavia ainesmääriä ja samalla muutetaan ympäristöä laajoilla alueil1a. Luonnon ekosysteemien vaurioituminen onkin muodostumassa raaka-aineiden riittävyyden ohella 


\section{AGRICULTURAL AND FOOD SCIENCE IN FINLAND}

\section{Risku-Norja, H. The total material requirement -concept applied to agriculture}

keskeiseksi kestävää kehitystä uhkaavaksi tekijäksi. Jotta tuotannon ympäristökuormitusta pystyttäisiin vähentämään, olisi luonnonvarojen käytöstä aiheutuvat ympäristöhaitat pystyttävä kvantifioimaan kansainvälisesti yhtenäisin menetelmin. Wuppertal-instituutti Saksassa ja eurooppalainen ConAccount -yhteisö (Coordiantion of Regional and National Material Flow Accounting for Environmental Sustainability) ovat 1990-luvulla kehitelleet materiaalivirtalaskentaa (MFA = Material Flow Accounting) tällaiseksi menetelmäksi.

MFA:n lähtökohtana on luonnonvarojen kokonaiskäyttö (TMR $=$ total material requirement). Tarkastelu perustuu aineen häviämättömyyden lakiin: luontoon takaisin palautuvan aineen määrä on sitä suurempi, mitä enemmän sieltä alunperin on raakaainetta otettu. Talouden läpi kulkeva materiaalivirta muodostuu paitsi suorista panoksista eli niistä aineista, joista eri tuotteet koostuvat myös ns. piilovirroista. Piilovirrat ovat niitä luonnonvaroja, joita käsitellään hyödykkeen valmistusprosessin aikana, mutta jotka eivät siirry lopputuotteeseen. Taloudellisen toiminnan ympäristövaikutukset määräytyvät materiaalivirtojen määrän ja laadun mukaan, ja siksi ihmisen aiheuttaman ympäristökuormituksen yleismittarina voidaan pitää luonnonvarojen kokonaiskäyttöä.

Materiaalivirtatarkastelu on eräs tapa arvioida kestävän kehityksen toteutumista: pienentämällä käyttöönotettavien raaka-aineiden määrää vähennetään ei-toivottuja ympäristövaikutuksia materiaalivirran alkupäässä. Samalla ehkäistään ympäristökuormitusta ennalta, sillä materiaalivirran supistuminen johtaa väistämättä päästö- ja jätemäärien pienenemiseen ja vähentää siten taloudellisen toiminnan ympäristökuormitusta myös materiaalivirran loppupäässä. Materiaalivirtojen supistamiseen liittyy läheisesti ekotehokkuusajattelu. Käsitteellä ekotehokkuus tarkoitetaan sellaisia toimintamenetelmiä, jotka tähtäävät ympäristökuormituksen pienentämiseen ilman, että tuotannon kokonaiskannattavuus ja taloudellinen hyvinvointi kärsivät. Tavoitteena on vähentää energian ja materiaalien käyttöä sekä päästöjä tuotantoyksikköä kohden ja samalla tuottaa kustannussäästöjä ja kilpailuetua. Tuotannon ekotehostamispyrkimykset konkretisoidaan Factor-tavoitteiden avulla. Kun pyrkimyksenä on alentaa tuotannon materiaali-intensiteettiä tuotettua yksikköä kohti, ei myöskään välttämättä jouduta ristiriitaan talouden ja hyvinvoinnin kasvutavoitteiden kanssa. Samaan tavoitteeseen voidaan päästä joko pienentämällä tuotantoon käytettävää raaka-aine- ja energiapanosta, kasvattamalla tuo- tantoa käytettyä panosta kohti tai toteuttamalla toimenpiteet samanaikaisesti.

Tässä tutkimuksessa on kuvattu maatalouden luonnonvarojen kokonaiskäytön nykytaso ja kehityssuunta Suomessa 1970-luvulta alkaen. Maatalouden ja sitä lähellä olevien tuotantosektorien kokonaismateriaalikulutus nykyisin on noin 30 miljoonaa tonnia - noin 6 tonnia asukasta kohti - vuodessa. Piilovirtojen osuus tästä on lähes $60 \%$. Kasvinviljelyn lisäbiomassa sekä arvioitu erodoituvan maa-aineksen määrä muodostavat tonnimääräisistä piilovirroista noin $90 \%$. Suhteessa viljelypinta-alaan maatalouden tuotanto on tarkasteluajanjaksona liki kaksinkertaistunut. Myös asukasmäärään suhteutettuna kokonaistuotantomäärä on kasvanut noin $25 \%$. Tuotannon tehostuminen on kuitenkin ollut hyvin energiaintensiivistä, sillä 1990-luvun alkuun mennessä on myös energiankulutus viljelypinta-alaa kohti kasvanut noin $70 \%$. Sen jälkeen viljelypinta-alaa kohti laskettu energiankulutus näyttää vakiintuneen tuolle tasolle. Lannoitteiden ja biosidien käytön kehitys on ollut samankaltainen: hehtaarisadot ovat kasvaneet samaa tahtia maatalouskemikaalien käytön kanssa aina 1990-luvun alkuun asti. 1990-luvulla saavutettu hehtaarisatotaso on säilynyt, vaikka lannoitteiden ja torjunta-aineiden käyttö viljelypinta-alaa kohti on jyrkästi vähentynyt. Hehtaarisadoissa sen sijaan ei ole tapahtunut merkittäviä muutoksia 1990-luvulla. Kehityssuunnat hehtaarisatomäärissä ja viljelypinta-alaa kohti lasketussa maatalouskemikaalien käytössä ovat selkeästi erkaantuneet, ja voidaan puhua orastavasta tuotannon ekotehostumisesta. Kehityksen taustalla olevia syitä selvitetään ja keskukstellaan mahdollisuuksista vähentää luonnonvarojen kokonaiskäyttöä edelleen.

Tutkimuksessa osoitetaan MFA-menetelmän soveltuvuus ja keskeiset kehittämistarpeet nimenomaan maataloudessa. TMR:aan perustuvia tunnuslukuja ei sellaisenaan aina voi käyttää, sillä tuotannon määrä riippuu viljelypinta-alasta ja sen arvonlisäyksen sanelee pitkälti harjoitettu maatalouspolitiikka. Maatalouden kestävyyttä materiaalivirta-analyysin menetelmin arvioitaessa on otettava huomioon hehtaarisadot sekä tuotantoon käytetyt panokset muilta tuotantosektoreilta, jotka ovat ratkaisevalla tavalla riippuvaisia viljelypinta-alasta. Aineiston perusteella on laskettu kolme tunnuslukua - ¿DMI/energiankulutus, $\sum$ DMI/ lannoitteiden käyttö, $\Sigma$ DMI/biosidien käyttö, joiden avulla voidaan arvioida maatalouden ekotehokkuutta ja muutosnopeutta kestävämpään suuntaan. 